\section{Det nye NFUD styret}

Ved årets symposium på Røros i april i år stod valg av ny styreleder og flere nye styremedlemmer på tur.

Utfra foreningens lover kunne tidligere leder Roald Flesland Havre, som styrte foreningen de siste 4 årene, ikke velges igjen. Det samme gjaldt sekretæren Eva Tegnander og styremedlemmene Rune Hansen og Vivi Bakkeheim.

Det nye styret har 11 medlemmer, altså 2 mer enn det gamle. Intensjonen med dette er å få flere faggrupper inni styret og rekruttere flere potensielle interessenter for våre symposier.

Ny leder er tidligere styremedlem Nils Petter Oveland, anestesilege og akuttmedisiner ved Stavanger Universitetssjuke-

hus og Stavanger Universitet. Han er spesielt interessert i "Point-of-care" diagnostikk med fokus på dette ultralydundersøkelser.

Ny nestleder og sekretær er Kari Utne, jordmor ved Stavanger Universitetssjukehus og i egen privatpraksis. Hun har alle-

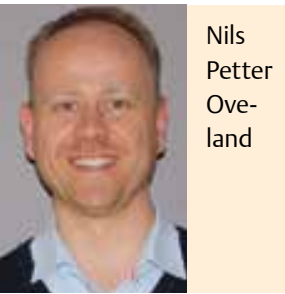
rede vært med i styret de siste 2 årene. Hun har tatt videreutdanning i ultralyddiagnostikk for jordmødre og videreutdanning i ultralydundersøkelsen av fosterhjertet ved NTNU. Hun er spesielt interessert i obstetrisk ultralyd og fosterdiagnostikk.

Anette Hem
Johnsen, jord-
mor ved Sørlan-
det sykehus
Arendal, er ny i
styret og tar di-
rekte på seg an-

svar som varasekretær. Også hun er videreutdannet i ultralyddiagnostikk for jordmødre ved NTNU. Hun er opptatt av å bruke obstetrisk ultralyd og prenatal diagnostikk effektivt i sin kliniske hverdag som jordmor.

Thomas Reiher fortsetter som kasserer, en oppgave som han allerede de siste 6 årene har løst glimrende. Med tanke på konti-

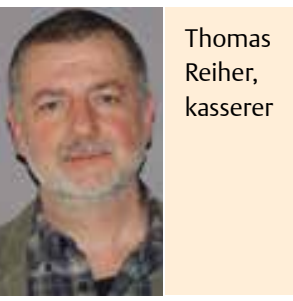
nuitet i styrets arbeid var det sterkt ønsket, at han skulle fortsette utover de to periodene, en kan gjenvelges ut fra foreningens lover. Generalforsamlingen vedtok valgkomiteens forslag, som først kan endelig godkjennes av neste års generalforsamling. Thomas Reiher er siden 1989 spesialist i pediatri. Han jobber som pediatrisk overlege og barnegastroenterolog ved Barneklinikken på Haukeland Universitetssykehus i Bergen.

Beatrice Rüger fortsetter ytterligere to år etter å ha representert ultralydinteresserte radiologer $\mathrm{i}$ styret allerede de siste 4 årene.

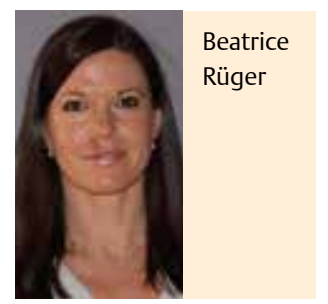
Hun har siden 2009 jobbet som radiologisk overlege ved Sykehuset Telemark HF Skien med hovedvekt innen ultralyd og intervensjon. Fra 2014 har hun vært 50\% på Brystdiagnostisk senter i Porsgrunn og $50 \%$ på ultralyd og intervensjonsseksjon ved radiologisk avdeling i Skien.

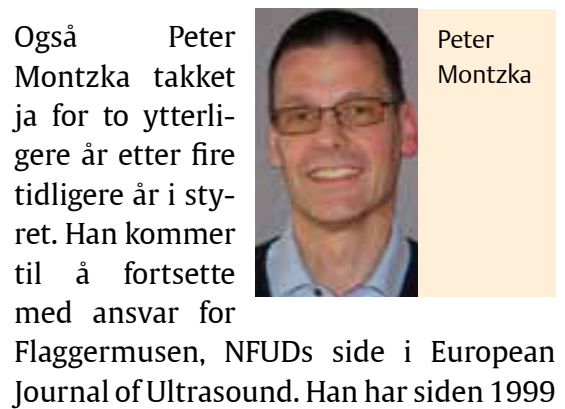

jobbet som overlege ved Kvinneklinikken Møre og Romsdal, Ålesund sjukehus, og har regelmessig vikariert ved både Nasjonalt Senter for Fostermedisin og Fertilitetsseksjonen ved St. Olavs Hospital i Trondheim. Hovedinteresse er prenatal og gynekologisk ultralyd og kvinnelig infertilitet.

De følgende 5 medlemmene er ny i styret.

Morten Glasø er
fastlege ved
Stallbakken le-
gesenter i Rælin-
gen kommune
og samhand-
lingsoverlege ved Avdeling for

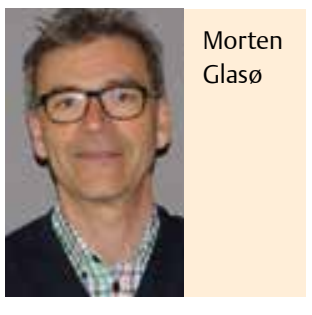
samhandling og

helsefremming, Akershus Universitetssykehus. Han jobber med å fremme pasientnær (bedside) ultralyd med sikte på mer effektiv diagnostikk og behandling i kommunehelse-, legevakt- og spesialisthelsetjenesten.

Kim Nylund er
lege og post.doc
ved Medisinsk
avdeling på Hau-
keland Universi-
tetssykehus i
Bergen. Han er
interessert i, og
har forsket på abdominal ultralyd med fo-
kus spesielt på ultralyd av mage-tarmka-
nalen. I 2013 fikk han tildelt NFUDs
forskerstipend.




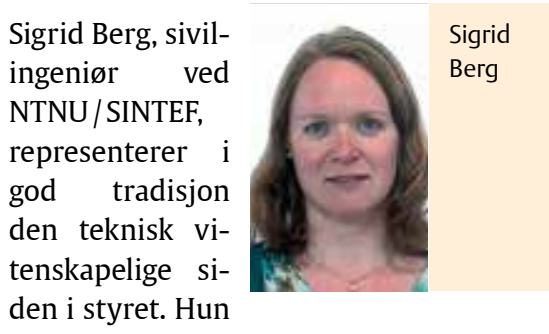

er utdannet sivilingeniør fra NTNU og jobber som forsker og post.doc ved SINTEF, Avdeling for medisinsk teknologi, og NTNU, Institutt for sirkulasjon og bildediagnostikk. Hun forsker innen bruk av ultralydkontrastmidler (mikrobobler) i avbildning av mikrosirkulasjon og innen terapi, f. eks. målrettet medisinlevering og åpning av blod-hjerne barrieren.

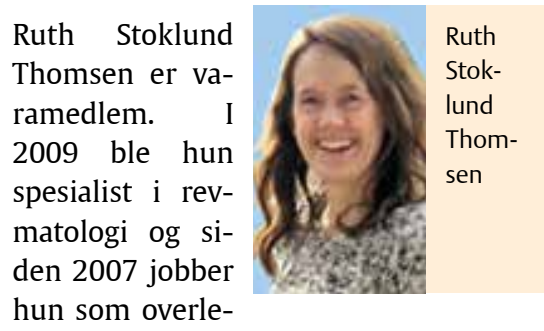
hun som overle-

ge ved revmatologisk avdeling, St. Olavs Hospital i Trondheim. Hun bruker ultralyd daglig til diagnostikk av leddsykdommer og terapeutiske injeksjoner i ledd. Hun driver et prosjekt hos pasienter med psoriasis artritt, hvor det utføres ultralyd av ledd og entheser etter omfattende protokoll.
Også Dan Skoglund er varamedlem. Han er 6. års medisinstudent ved Syddansk Universitet i Danmark og jobber som tur-

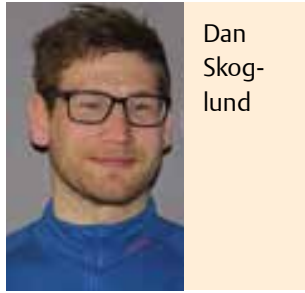
nuslegevikar ved Nordlandssykehuset. Hans interesseområde er Point-of-care ultralyd og innføring av ultralyd som obligatorisk kurs i medisinstudiet. Dan Skoglund har holdt på med å lage NFUDs nye nettside, som forventes å være oppe i løpet av juli. 